Indexed by

\title{
Scopus
}

\section{THE GEOLOGICAL STRUCTURE EFFECTS ON SLOPES STABILITY AND TUNNELS OF METAMORPHIC ROCKS AT POBOYA GOLD MINE PALU}

Crossref

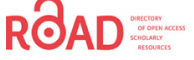

KOBSON

I8 Google

\section{Ahmad Rifa'i}

Department of Civil and Environmental Engineering, Gadjah Mada University, Indonesia

\author{
Sriyati Ramadhani \\ Department of Civil \\ Engineering, Tadulako \\ University, \\ Indonesia
}

\author{
Wahyu Wilopo \\ Department of Geological and \\ Center for Disaster Mitigation \\ Technological Innovation \\ (GAMA-InaTek), Gadjah \\ Mada University, \\ Indonesia
}

Key words: geological structure, slope stability, tunnels, metamorphic rock, gold mine doi:10.5937/jaes0-31839

Cite article:

Rifa'i A., Ramadhani S., Wilopo W. (2022) THE GEOLOGICAL STRUCTURE EFFECTS ON SLOPES STABILITY AND TUNNELS OF METAMORPHIC ROCKS AT POBOYA GOLD MINE PALU, Journal of Applied Engineering Science, 20(1), 1 - 12, DOI:10.5937/ jaes0-31839 


\title{
THE GEOLOGICAL STRUCTURE EFFECTS ON SLOPES STABILITY AND TUNNELS OF METAMORPHIC ROCKS AT POBOYA GOLD MINE PALU
}

\author{
Ahmad Rifa'i'*, Sriyati Ramadhani', Wahyu Wilopo ${ }^{3}$ \\ ${ }^{1}$ Department of Civil and Environmental Engineering, Gadjah Mada University, Indonesia \\ ${ }^{2}$ Department of Civil Engineering, Tadulako University, Indonesia \\ ${ }^{3}$ Department of Geological and Center for Disaster Mitigation Technological Innovation \\ (GAMA-InaTek), Gadjah Mada University, Indonesia
}

Poboya area has many geological structures that result in distribution of strength and stress of rocks not evenly distributed, as a result, the rock mass strength becomes disturbed and slopes become unstable. The objective of the study was to determine the geological structure effect on slope stability and tunnel conditions on metamorphic rocks at the Poboya gold mine. The study was conducted in the Mantikulore sub-district, Palu, Central Sulawesi. Lithology composing study area is metamorphic rocks consisting of gneiss and schist, therefore, the analysis was carried out on both locations which have many geological structures. Numerical analysis was performed applying the finite element method with the RS2 program assistance. The findings show that the safety factor value of the existing slope at gneiss and schist location under static loading is 4.6 and 2.72, if there is an earthquake it becomes 1.07 and 0.77. The safety factor value under static loading with the joint is 4.58 and 2.03, while under dynamic loading with joint, it becomes 0.94 and 0.64 . The geological structure effect which represented by the joint gave a big impact with a decrease of safety factor at gneiss about $0.43 \%$ under static loading and $80 \%$ under dynamic loading. Meanwhile, at schist, safety factor decreased $25 \%$ under static loading and $76 \%$ under dynamic loading. For tunnel stability, the existence of joint will increase the displacement of $65 \%$ at gneiss under static loading and $84 \%$ under dynamic loading, while at schist, it increases $25 \%$ under static loading and $54 \%$ under dynamic loading. This illustrates that geological structures under dynamic loading affect significantly slope stability of Poboya gold mine.

Key words: geological structure, slope stability, tunnels, metamorphic rock, gold mine

\section{INTRODUCTION}

Gold is a mineral commodity that has a fairly high selling price. Indonesia has many areas that store gold deposits on the surface, including the Poboya region [1]. The Poboya area has vein textures in the form of banded and comb textures as well as sulfide minerals such as pyrite and chalcopyrite in rock samples in the area which are characteristic of epithermal deposits [2]. In that area it is also found the produced ore remnants containing a lot of heavy metals, especially the heavy metal cadmium [3] [22].

Based on sources obtained from Poboya residents, there are many traditional gold mines in several locations at Poboya in the form of a small-scale gold mine which is still in operation. It is estimated that the geological conditions resulting in alteration and mineralization controlled by the geological structure zone that works in the area. As a result of the combination of mining activities on the local geological conditions, it causes slope instability in the mining area.

The rock slopes instability occured because of high and steep rock slope, geological and topographical conditions as well such as the deeper down-cutting of river and weak layers [4]. Failure of rock slopes controlled by structural discontinuities, which have large-scale move- ments and deformations [5]. Discontinuity orientation is the main geological factor that affects slope stability [6], whereas according to [7] that the stability of rock slope is highly affected by distribution and strength of joints. The joint structure criteria that affect reducing slope stability according to [8] are slope direction (dip direction) of joint structure, location and distance of joint structure to slope, thickness of joint structure and intensity of joint structure. In accordance wtih [9] that the scale effect is very important in determining the strength of rocks. One reason is the influence of the distance of joint planes.

The Poboya area is a traditional mining area, where the area has many discontinuities [10]. Factors that cause the instability of slopes are the existence of discontinuity plane or geological structure on slopes as seen in Figure 1 which shows condition of slopes and tunnels in Poboya gold mine where there are many geological structures can be found. Traditional miners in conducting mining activities do not pay attention to safety aspects. The safety factor considered as the most important aspect of slope stability, for it can result in negative impacts such as social impacts that may cause feeling unsafe. In accordance with the above description, it is necessary to analyze the stability of slopes and tunnels at Poboya in terms of the impacts of geological structure.

There are several methods used in modeling geological 
structures to be analyzed, including the finite difference method and the finite element method. According to [11] that the finite element method is one of the most powerful approximate solution methods that can be applied to solve various problems represented by ordinary or partial differential equations.

The FEM offers a number of advantages over traditional method-of-slices analysis [12] including:

1. Elimination of a priori assumptions on the shape and location of failure surfaces;

2. Elimination of assumptions regarding the inclinations and locations of interslice forces;

3. Capability to model progressive failure;

4. Calculation of deformations at slope stress levels, and;

5. Robustness - ability to perform successfully under a wide range of conditions.

The study aimed at determining the impacts of geological structure on slope stability conditions and tunnels on metamorphic rocks in the Poboya gold mine based on the finite element method using the RS2 software [13]. The study conducted in Poboya gold mine which is located geographically, in Mantikulore district, Palu, Central Sulawei province (Figure 3).

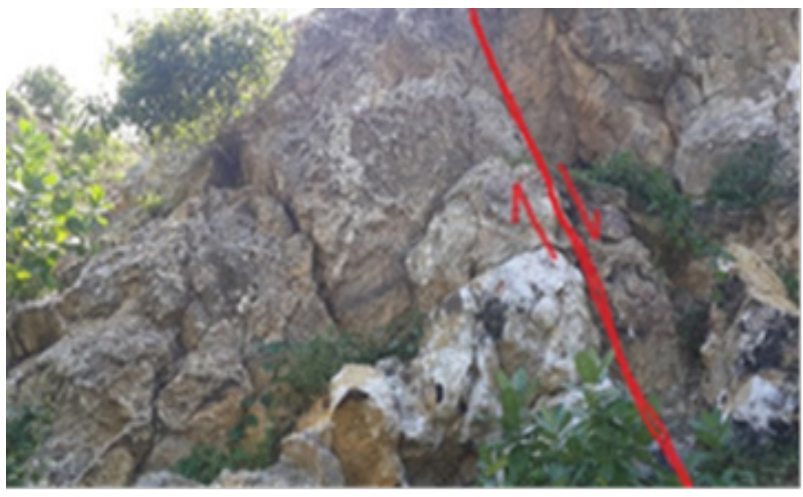

Figure 1: Appearance of the geological structure of Poboya gold mine (faults on slope)

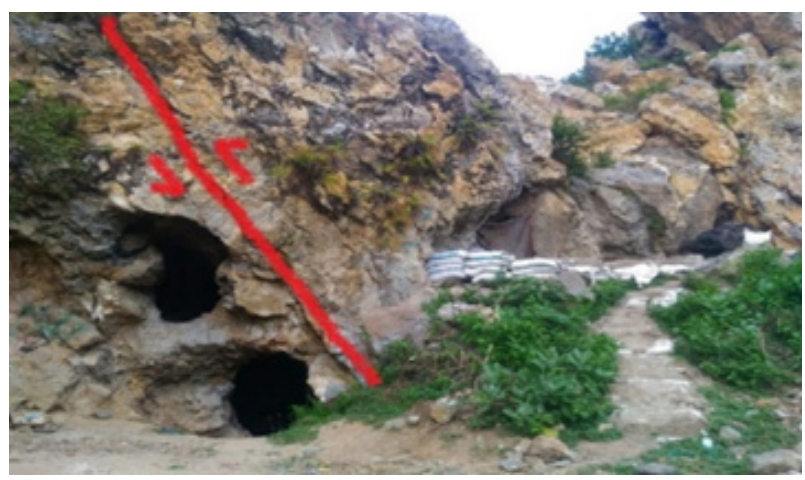

Figure 2: Appearance of the geological structure of Poboya gold mine ( faults in tunnel)

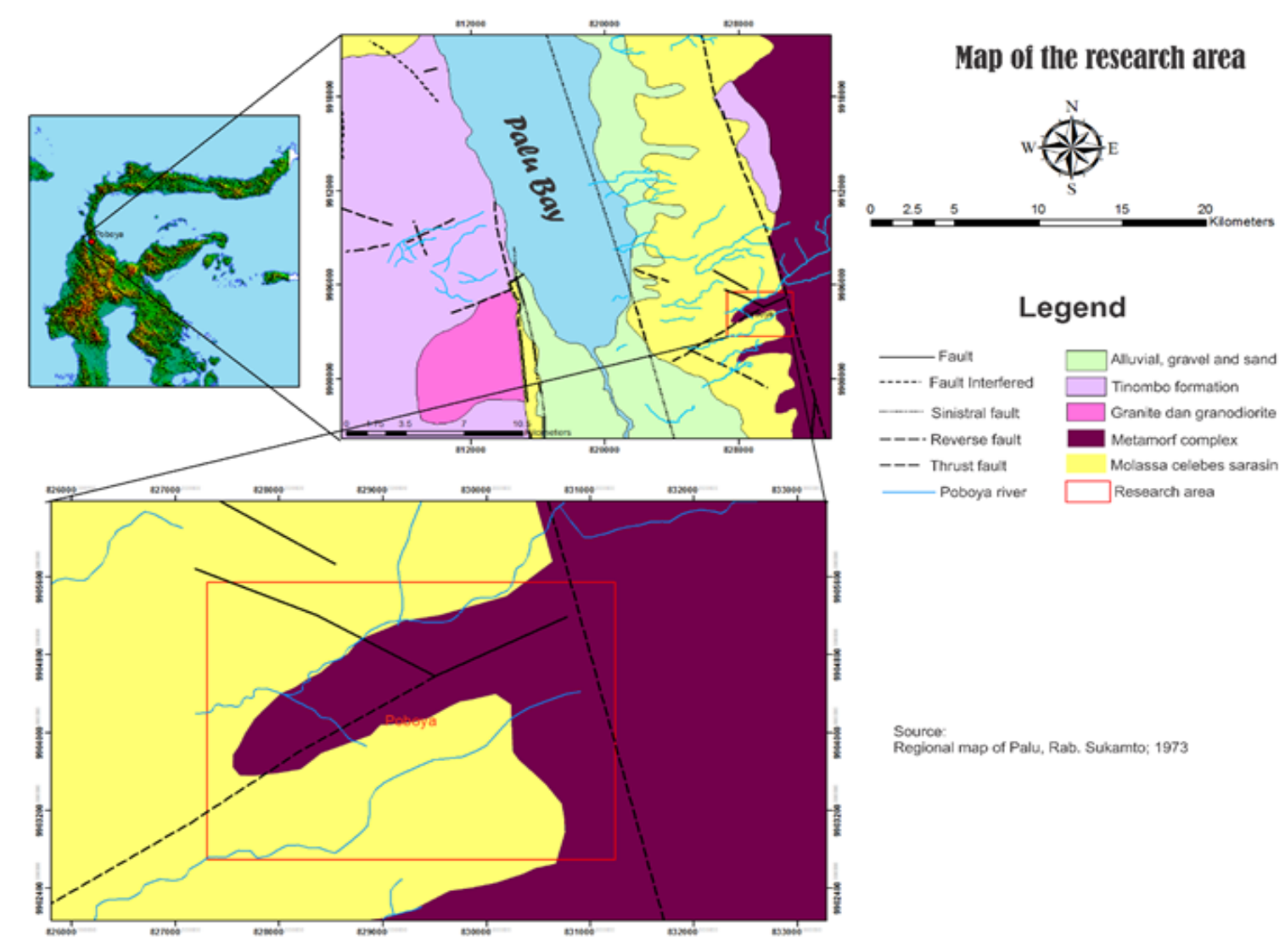

Figure 3: Map of research site 


\section{The Geological Conditions of Poboya}

Sulawesi Island can be divided into two parts, namely West anc $;$ is dominated by volcanic $\square$ icks. The East Zone incluc

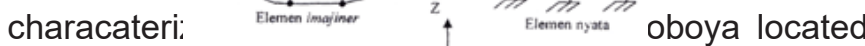
in the Easte $\longrightarrow$ he main basin of Palu Kor ıwesi Island in

Neogen [15].

In regards to geological structure, Palu Koro fault considered as the main structure forming channel as a mineralized carrier fluid path. Metamorphic rocks from the Toboli Formation are the main rocks of the dominant mineralization. The mineralized zone is associated with quartz-carbonate veins and vein breccias with a banded, chalchedonic, and bladed dominant texture. The veins contain many episodes of the precipitation phase of quartz-carbonate [16].

The rocks composition of Poboya area based on stratigraphic sequence from old age to young [17] as follows:

a. Metamorphic rock

These rocks are found around the eastern border of the study area which is also Palu district boundary with Parimo. Schist rocks are generally clogged with more intensive surface weathering. The areas composed by these rocks are generally vegetated, so that relatively intact rock physical conditions can only be observed around the river cliffs in the northeast or upstream of the Poboya River.

\section{b. Intrusion rock}

The intrusion rocks in the study site are found in relatively small masses as well as local intrusive bodies that infiltrate the older rocks. The physical properties of the rocks are fractured, fragmented and partly weathered.

\section{c. Sedimentary rock type molasses}

These rocks consisted of conglomerate, sandstone, silt, and clay. The rocks spread in the study site is very large and considered as dominant composer about $90 \%$ dominates the distribution of composer rock. The nature of bedding that is not constantly on this rock in some places can be observed mainly in the cliffs Poboya River.

\section{d. Alluvial rock}

This material is a composition of Poboya river region which is characterized by terrain morphology. The composition of this alluvial fragment consists of schist, gneiss, diorite, basalt and granite

\section{Finite Element Method (FEM)}

The finite element method divided into five steps [18] namely,

a. Discretizing structures into elements (real or imaginary), with intersecting grid lines at nodal

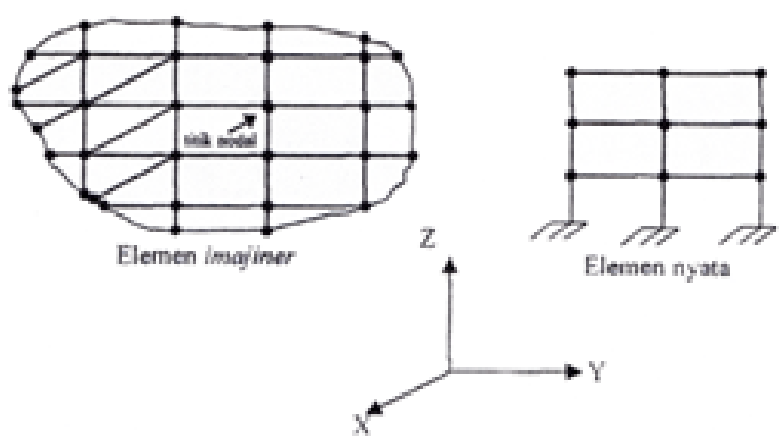

Figure 4: Nodes in real or imaginary elements intersect at nodal points [18].

points as can be seen in Figure 3.

b. Specifying the approximate function for each element and expressing the displacmenet components $\mathrm{u}, \mathrm{v}$ dan $\mathrm{w}$,

c. Obtaining the stiffness matrix of each element used from the description of the balance equation obtained by the principle of potential energy,

d. Solving the problem after obtaining the solution for nodal displacements of unknown structures by calculating the boundary conditions previously,

e. Based on the previously obtained nodal displacement, the amount of stress, strain, and internal forces for each element can be identified.

The finite element method is one of the most powerful approximate solution methods that can be applied to solve various problems represented by ordinary or partial differential equations [11]. The strength of such a method stems from the fact that it can easily accommodate changes in material rigidity that are evaluated at the element level. Finite element modeling for the problem of soil-structure interaction must be carefully planned and carried out, so that any anomalies in the results can be identified and fixed. Generally, the size of the element used in a net depends on the conditions of loading and geometric discontinuity as stated above. Numerical evidence seems to illustrate that the elemental aspect ratio must remain within reasonable limits.

There are some two-dimensional element types, commonly used to solve plane stress, plane strain, and bending plate problems [18] as follows (Figure 4):

1. Triangle and quadrilateral elements are more flexible to be used to approach structures that have irregular geometry,

2. Rectangular elements are suitable for modeling structures that have a rectangular geometry or irregular inner parts and for the outside using triangular or quadrilateral elements. 


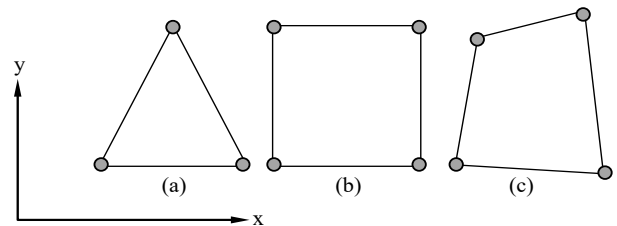

Figure 5: Two-dimensional element type: (a) triangle element, (b) rectangular element, (c) quadrilateral element [18].

The use of Finite Element Method (FEM) in the analysis of slope stability continues to increase. One of the most popular techniques for FEM slope analysis is the Shear Strength Reduction (SSR). SSR is a systematically method for reducing safety factors while modeling slope computationally with FEM [19]. The use of FEM theory with SSR is a method proposed for more accurate estimation of safety factors [19]. The Shear Strength Reduction (SSR) technique is a method of slope stability analysis using the program finite element or finite difference [20].

\section{RESEARCH METHOD}

In analyzing slope stability, the finite element method employed with the RS2 software assistance. This analysis can model geological conditions such as faults or discontinuities so as to provide a more realistic estimate of slope behavior. Modeling in this analysis using several limitations such as numerical models are made in the form of two-dimensional analyzed in plane strain, as a model approach and the material layer slope surface shape is based on the results of measurements in the field. The existing slope geometry has a slope height of $33 \mathrm{~m}$ with an overall slope of $19 \mathrm{o}$ and the tunnel diameter used is $2 \mathrm{~m}$ with a $5 \mathrm{~d}$ dimension detail below the surface of the tunnel, not less than $10 \mathrm{~d}$ above the tunnel peak and horizontally $6 \mathrm{~d}$ from the tunnel axis [11]. Tunnel and joint distances are made based on field measurements.

Model form calculations are performed on existing slopes and tunnels. Analysis was carried out under conditions of static loading, static loading with joint effect, conditions of dynamic loading and dynamic loading with joint effect. Slope and tunnel models are taken from the existing slope conditions at the Poboya gold mine.

The analysis results obtaining the safety factor value that calculated using the Shear Strength Reduction (SSR) method and total displacement value to identify the failure occurrence on slopes. The type of surface failure used in this study is the Mohr Coulomb failure criterion. Meanhile, the PGA value based on the ground vibration acceleration map [21] is $0.75 \mathrm{~g}$.

The lithology found in the Poboya gold mine is metamorphic rocks in the form of gneiss and schist. The slope stability analysis was carried out at two locations, the gneiss location at the coordinate point of $828149 \mathrm{mE}-$ $9904467 \mathrm{mS}$ and the schist location at the coordinate point of $828182 \mathrm{mE}-9904498 \mathrm{mS}$, where the location contained many geological structures and moreover, the miners carrying out excavation and cutting slopes to collect rocks containing gold ore.

The input parameters needed in the slope stability analysis of this model are material input parameters, joint input parameters and input parameters for network joint. The material input parameters used in slope stability analysis with the help of the RS2 program can be seen in table 1 and the input parameters for the joint network based on discontinuity orientation data can be seen in table 2

Table 1: Material input parameters used in the $R^{2}$

\begin{tabular}{|c|c|c|}
\hline Parameter & Gneiss & Schist \\
\hline $\begin{array}{c}\text { Unit Weight } \\
(\mathrm{kN} / \mathrm{m} 3)\end{array}$ & 25 & 25 \\
\hline Cohesion (kPa) & 291 & 129 \\
\hline$\phi\left(^{\circ}\right)$ & 28 & 25 \\
\hline Type Siffness & Isotropic & Isotropic \\
\hline $\begin{array}{c}\text { Young's } \\
\text { Modulus (kPa) }\end{array}$ & 4633000 & 15594000 \\
\hline Poisson's Ratio & 0.24 & 0.25 \\
\hline
\end{tabular}

Table 2: Material input parameters used in the $R^{2}$

\begin{tabular}{|c|c|c|}
\hline Parameter & Gneiss & Schist \\
\hline Joint Model & Baecher & Baecher \\
\hline Joint Property & Joint 1 & Joint 2 \\
\hline $\begin{array}{l}\text { Definition } \\
\text { Method }\end{array}$ & $\begin{array}{l}\text { Dip/Dip } \\
\text { Direction }\end{array}$ & $\begin{array}{c}\text { Dip/Dip } \\
\text { Direction }\end{array}$ \\
\hline Use Trace Plane & No & No \\
\hline Inclination & 69 & 58 \\
\hline $\begin{array}{l}\text { Mean Joint } \\
\text { Length }(\mathrm{m})\end{array}$ & 1 & 1 \\
\hline $\begin{array}{l}\text { Joint and } \\
\text { Condition }\end{array}$ & $\begin{array}{l}\text { Open at } \\
\text { Boundary } \\
\text { Contacts }\end{array}$ & $\begin{array}{c}\text { Open at } \\
\text { Boundary } \\
\text { Contacts }\end{array}$ \\
\hline
\end{tabular}

\section{RESULTS AND DISCUSSION}

Slope stability analysis using the finite element method reviewed at 2 location points with existing slope modeling and tunnels. Existing slopes and tunnels are 
analyzed based on 4 (four) conditions of static loading, static loading with joint effect, dynamic loading and dynamic loading with joint effect. The results of the analysis will be discussed in detail as follows.

Slope Modeling at Gneiss location at the coordinate point of $828149 \mathrm{mE}-9904467$

The results of slope stability analysis in gneiss using 2D finite element method can be seen in Table 3. The results obtained explain that the largest total displacement value at gneiss is at the peak of $0.247 \mathrm{~m}$ under dynamic loading with joint effect and for the smallest value of total displacement is at the bottom of slope at $0.00079 \mathrm{~m}$ which is under static loading. Deformation that occurs at gneiss can be seen in Figure 6 . The safety factor value is calculated using the Shear Strength Reduction (SSR) method. In this analysis, the hightest safety factor value is found on the slope about 4.6 under static loading and the lowest safety factor value found on the slope is 0.94 under dynamic loading with joint effect. The tunnel at the gneiss location has joints with a distance based on the size of the field which can be seen in Figure 6 , therefore in analyzing the tunnel it is highly influenced by the joint. The condition of the review of the tunnel deformation point at the gneiss location can be seen in Figure 8.

Table 3: Simulation results of slope stability with 2D finite element method for gneiss.

\begin{tabular}{|c|c|c|c|c|c|c|c|c|c|}
\hline \multirow[b]{2}{*}{ Lithology } & \multirow[b]{2}{*}{$\begin{array}{l}\text { Reviewed } \\
\text { Points of } \\
\text { Slope }\end{array}$} & \multicolumn{4}{|c|}{ Total Displacement (m) } & \multicolumn{4}{|c|}{ Stress Reduction Factor (SRF) } \\
\hline & & $\begin{array}{l}\text { Static } \\
\text { Loading }\end{array}$ & $\begin{array}{l}\text { Static } \\
\text { Loading } \\
\text { with } \\
\text { Joint }\end{array}$ & $\begin{array}{l}\text { Dynamic } \\
\text { Loading }\end{array}$ & $\begin{array}{c}\text { Dynamic } \\
\text { Loading } \\
\text { with } \\
\text { Joint }\end{array}$ & $\begin{array}{l}\text { Static } \\
\text { Loading }\end{array}$ & $\begin{array}{l}\text { Static } \\
\text { Loading } \\
\text { with } \\
\text { Joint }\end{array}$ & $\begin{array}{l}\text { Dynamic } \\
\text { Loading }\end{array}$ & $\begin{array}{c}\text { Dynamic } \\
\text { Loading } \\
\text { with } \\
\text { Joint }\end{array}$ \\
\hline \multirow{5}{*}{ Gneiss } & Buttom & 0.00079 & 0.00138 & 0.0123 & 0.039 & \multirow{5}{*}{4.6} & \multirow{5}{*}{4.58} & \multirow{5}{*}{1.07} & \multirow{5}{*}{0.94} \\
\hline & \multirow{2}{*}{ Middle } & 0.00751 & 0.00828 & 0.0171 & 0.0910 & & & & \\
\hline & & 0.00593 & 0.00736 & 0.0147 & 0.0910 & & & & \\
\hline & \multirow{2}{*}{ Peak } & 0.00672 & 0.00828 & 0.0147 & 0.0910 & & & & \\
\hline & & - & - & 0.0466 & 0.247 & & & & \\
\hline
\end{tabular}

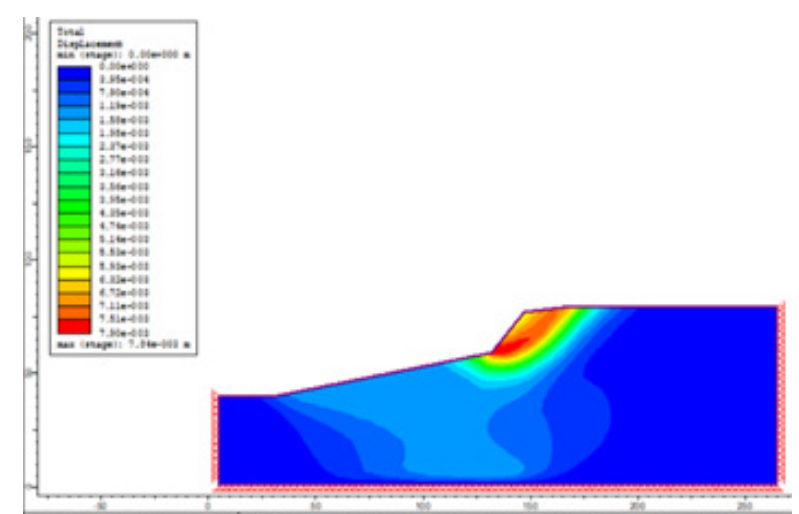

a)

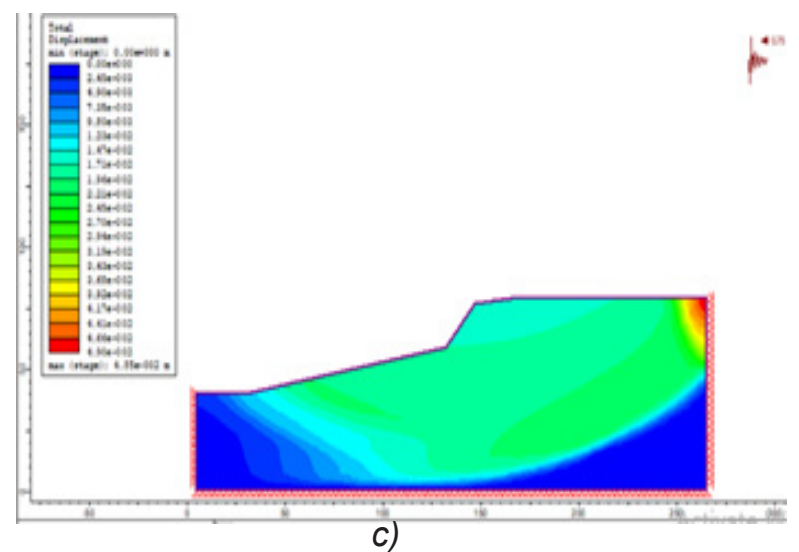

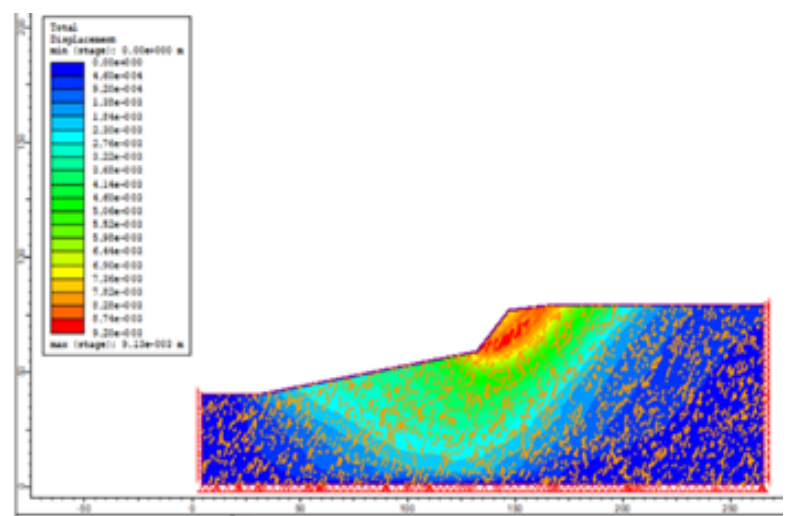

b)

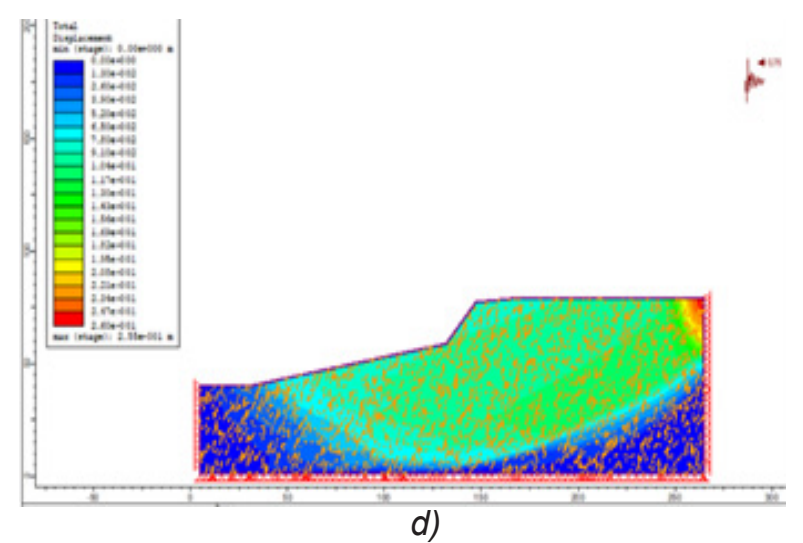

Figure 6: Distribution of total displacement for the slope model at gneiss with conditions a) Static loading, b) Static loading with joint, c) Dynamic loading, d) Dynamic loading with joint. 


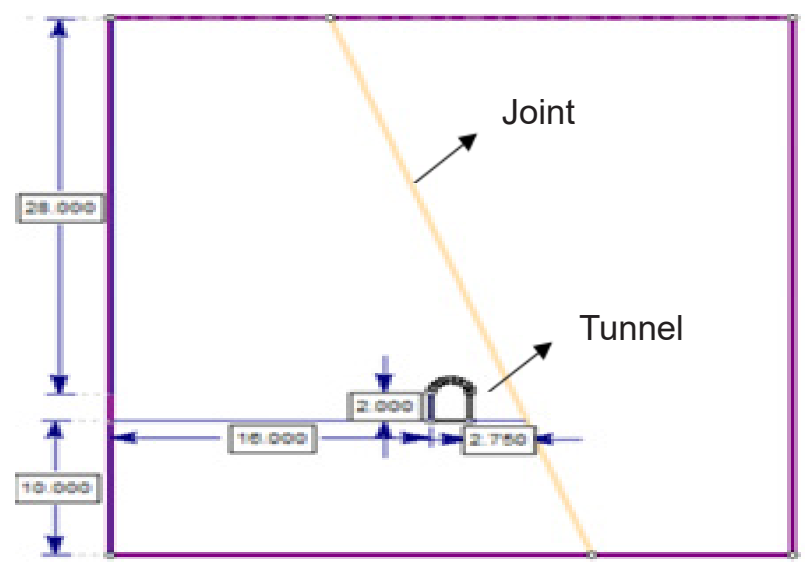

Figure 7: The detailed dimensions of tunnels and joints at gneiss.

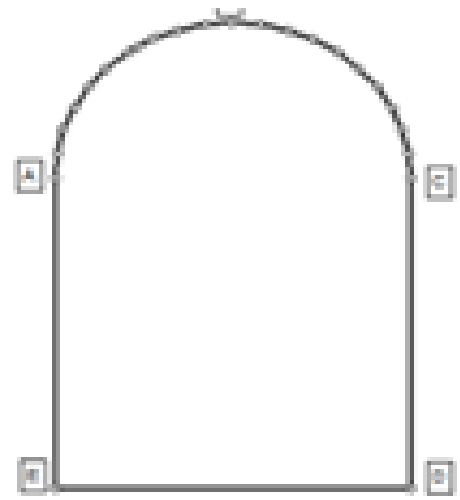

Figure 8: The location of deformation point review at gneiss.

Table 4: Material input parameters used in the $R S^{2}$

\begin{tabular}{|c|c|c|c|c|c|}
\hline \multirow{2}{*}{ Modeling } & \multicolumn{5}{|c|}{ Total Displacement (mm) } \\
\cline { 2 - 6 } & Point A & Point B & Point C & Point D & Point E \\
\hline Condition of static loading & 0.11 & 0.11 & 0.11 & 0.08 & 0.08 \\
\hline $\begin{array}{c}\text { Condition of static loading with joint effect beside the } \\
\text { tunnel }\end{array}$ & 0.13 & 0.18 & 0.11 & 0.09 & 0.09 \\
\hline $\begin{array}{c}\text { Condition of static loading with joint effect in the middle } \\
\text { of tunnel }\end{array}$ & 0.18 & 0.32 & 0.23 & 0.09 & 0.14 \\
\hline $\begin{array}{c}\text { Condition of dynamic loading } \\
\text { Condition of dynamic loading with joint effect beside } \\
\text { tunnel }\end{array}$ & 0.46 & 0.60 & 0.63 & 0.56 & 0.53 \\
\hline $\begin{array}{c}\text { Condition of dynamic loading with joint effect in the } \\
\text { middle of tunnel }\end{array}$ & 0.38 & 0.68 & 0.71 & 0.60 & 0.45 \\
\hline
\end{tabular}

The results of the tunnel deformation analysis of gneiss in the form of total displacement can be seen in Table 4 . The Table showed, the maximum tunnel displacement at gneiss under static loading in points $A, B$ and $C$ is 0.11 $\mathrm{mm}$. For static loading condition which affected by the joint inside of the tunnel, the maximum total displacement value at point $B$ is $0.18 \mathrm{~mm}$, for static loading condition with joint effect inside the tunnel, the maximum total displacement value at point $B$ is $0.32 \mathrm{~mm}$. In condition of dynamic loading, the maximum total displacement value at point $\mathrm{C}$ is $0.63 \mathrm{~mm}$, while condition of dynamic loading with the joint effect in side of the tunnel, the max- imum total displacement value at point $C$ is $0.67 \mathrm{~mm}$, while condition of dynamic loading with joint effect in the middle of the tunnel, the maximum total displacement value at point $C$ is $0.71 \mathrm{~mm}$. Considering the obtained values, it described the deformation that occurs around the tunnel is very small. Deformation behavior in tunnels due to total displacement as shown in Figure 8. The total displacement behavior displayed is in shading. The blue color shows the smallest total displacement value, while the red gives the largest total displacement value. 


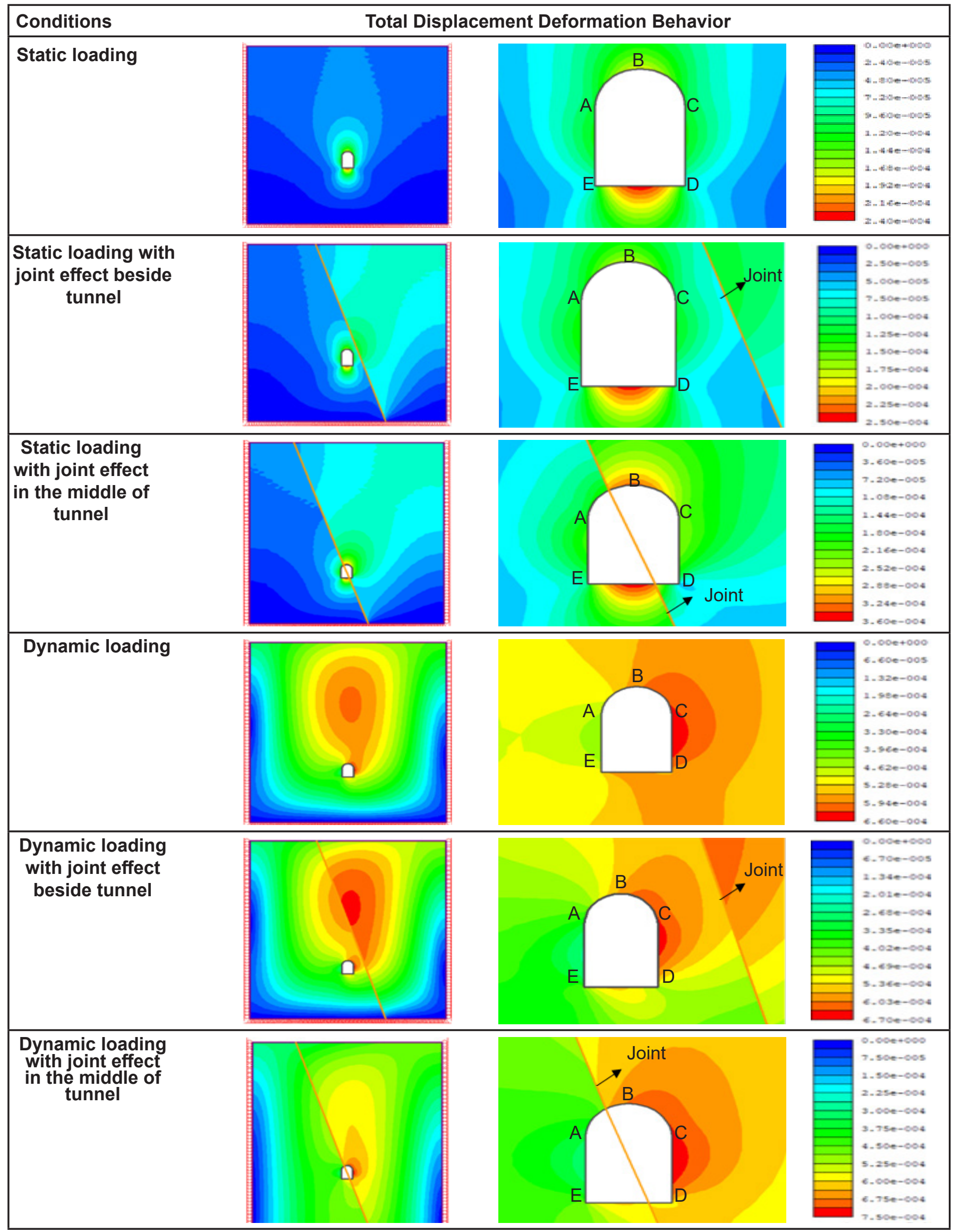

Figure 9: Tunnel deformation behavior at gneiss due to the total displacement 


\section{Slope Modeling at Schist Location at the coordinat point of $828182 \mathrm{mE}-9904498 \mathrm{mS}+$}

The results of slope stability analysis in schist using $2 \mathrm{D}$ finite element method can be seen in Table 5. The results obtained explain that the largest total displacement value in schist is found at the peak of the slope under dynamic loading with joint effect about $0.0399 \mathrm{~m}$ and the smallest value of total displacement is at the bottom of the slope under static loading of $0.00018 \mathrm{~m}$. Deformation that occured in schist can be seen in Figure 9. The safety factor values are calculated using the Shear Strength Reduction (SSR) method. Through this analysis, it is found that the highest safety factor found on the slope under dynamic loading about 2.72 and the lowest safety factor found on the slope under dynamic loading with joint effect is 0.64

Table 5: Simulation results of slope stability with 2D finite element method for schist

\begin{tabular}{|c|c|c|c|c|c|c|c|c|c|}
\hline \multirow[b]{2}{*}{ Lithology } & \multirow[b]{2}{*}{$\begin{array}{c}\text { Reviewed } \\
\text { Points of } \\
\text { Slope }\end{array}$} & \multicolumn{4}{|c|}{ Total Displacement $(\mathrm{m})$} & \multicolumn{4}{|c|}{ Stress Reduction Factor (SRF) } \\
\hline & & $\begin{array}{c}\text { Static } \\
\text { Loading }\end{array}$ & $\begin{array}{c}\text { Static } \\
\text { Loading } \\
\text { with } \\
\text { Joint }\end{array}$ & $\begin{array}{l}\text { Dynamic } \\
\text { Loading }\end{array}$ & $\begin{array}{c}\text { Dynamic } \\
\text { Loading } \\
\text { with } \\
\text { Joint }\end{array}$ & $\begin{array}{l}\text { Static } \\
\text { Loading }\end{array}$ & $\begin{array}{c}\text { Static } \\
\text { Loading } \\
\text { with } \\
\text { Joint }\end{array}$ & $\begin{array}{l}\text { Dynamic } \\
\text { Loading }\end{array}$ & $\begin{array}{c}\text { Dynamic } \\
\text { Loading } \\
\text { with } \\
\text { Joint }\end{array}$ \\
\hline \multirow{5}{*}{ Schist } & Buttom & 0.00018 & 0.00405 & 0.00195 & 0.0084 & \multirow{5}{*}{2.72} & \multirow{5}{*}{2.03} & \multirow{5}{*}{0.77} & \multirow{5}{*}{0.64} \\
\hline & \multirow{2}{*}{ Middle } & 0.00108 & 0.0135 & 0.0039 & 0.0147 & & & & \\
\hline & & 0.00096 & 0.0243 & 0.0039 & 0.0126 & & & & \\
\hline & \multirow{2}{*}{ Peak } & 0.00054 & 0.027 & 0.0039 & 0.0126 & & & & \\
\hline & & - & - & 0.0117 & 0.0399 & & & & \\
\hline
\end{tabular}

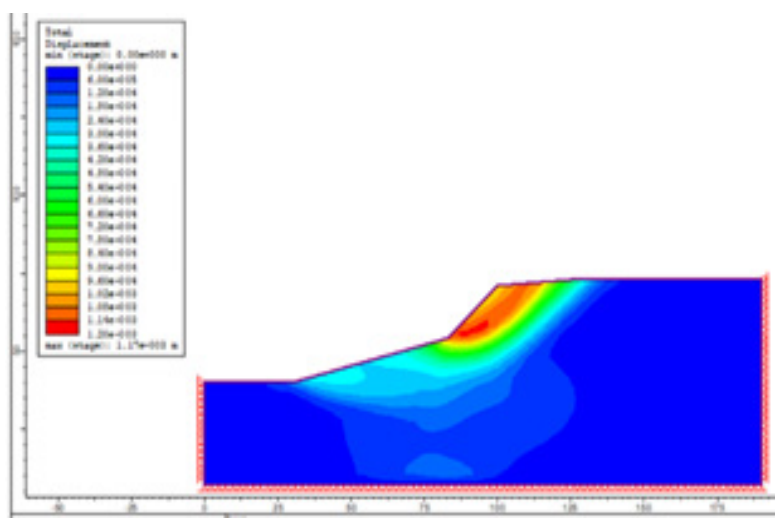

(a)

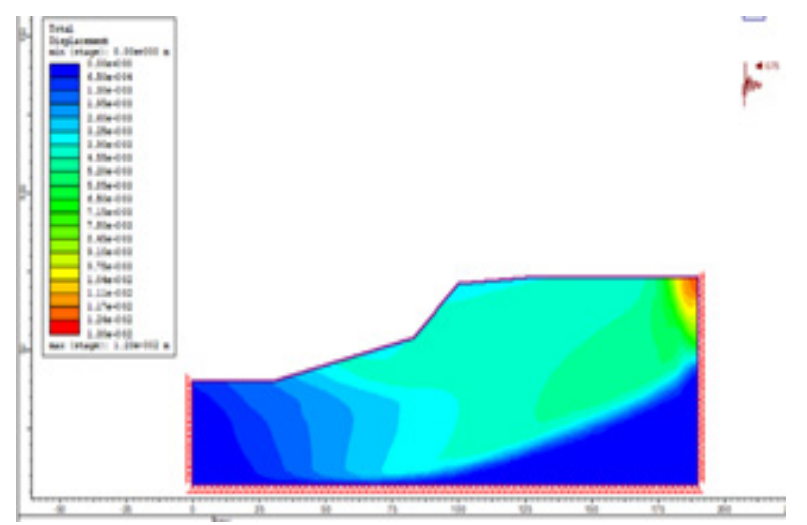

(c)

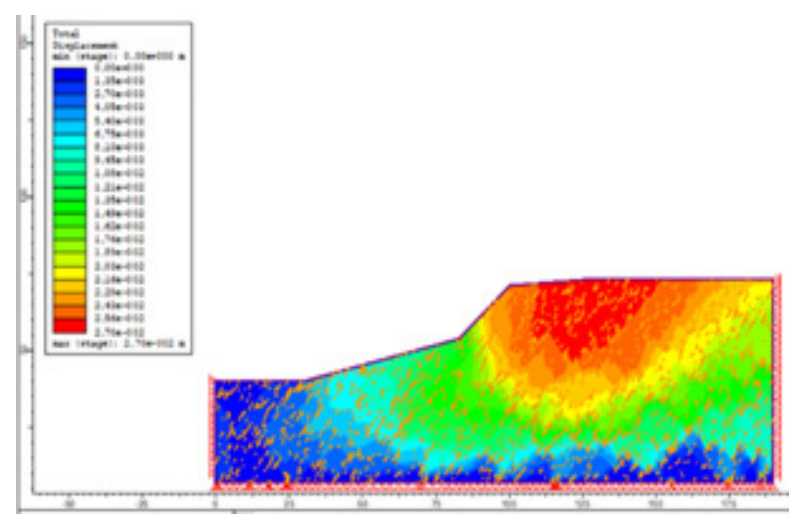

(b)

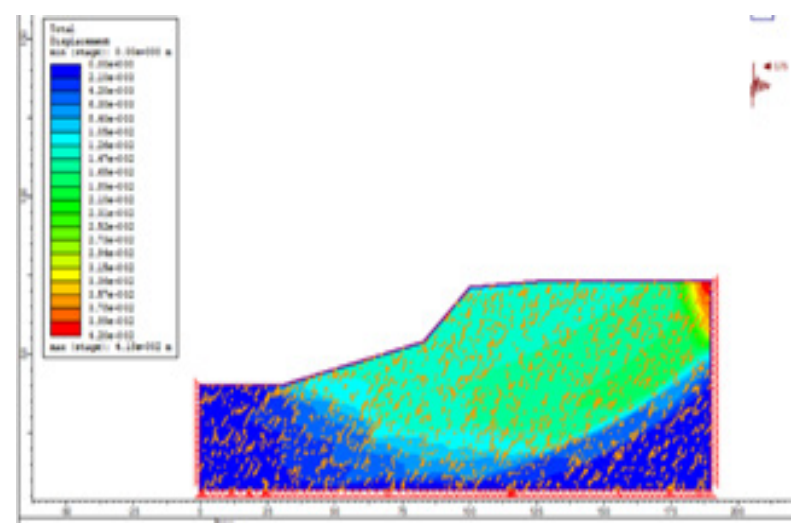

(d)

Figure 10: Distribution of total displacement for the slope model at schist with conditions a) Static loading, b) Static loading with joint, c) Dynamic loading, d) Dynamic loading with joint 
The tunnel at gneiss has joints with a distance based on the field size which can be seen in Figure 11, therefore, int analyzing the tunnel it is highly influenced by joint. The condition of the review of tunnel deformation point at gneiss can be seen in Figure 12. Results of the analysis in Table 6 explain that the maximum total tunnel displacement at schist under static loading at point $F$ is $0.38 \mathrm{~mm}$ and under static loading with joints effect occur at point $F$ is $0.51 \mathrm{~mm}$. Under conditions of dynamic loading, the maximum total displacement value is at points
$\mathrm{C}$ and $\mathrm{F}$ aboout $0.56 \mathrm{~mm}$ and under condition of dynamic loading with joint effect, the maximum total displacement value is at point $\mathrm{F}$ about $0.83 \mathrm{~mm}$. The obtained values describe the deformation that occured around the tunnel is very small. Deformation behavior in tunnels due to total displacement as shown in Figure 12. The total displacement behavior displayed is in shading. The blue color shows the smallest total displacement value, while the red gives the largest total displacement value.

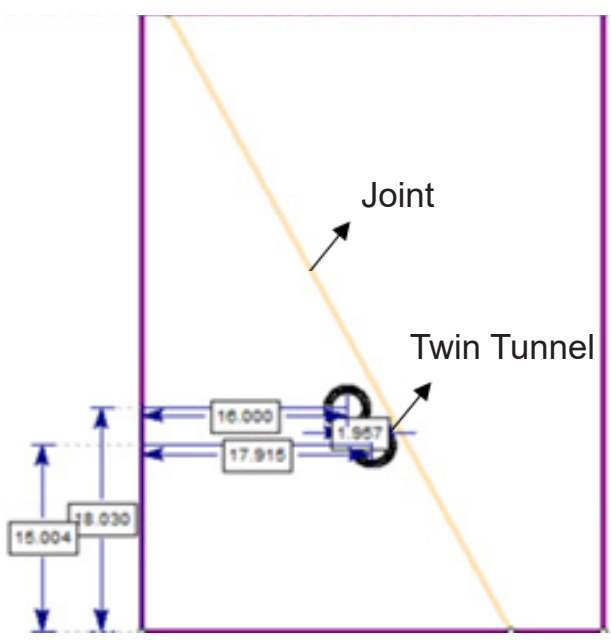

Figure 11: The detailed dimensions of tunnels and joints at schist

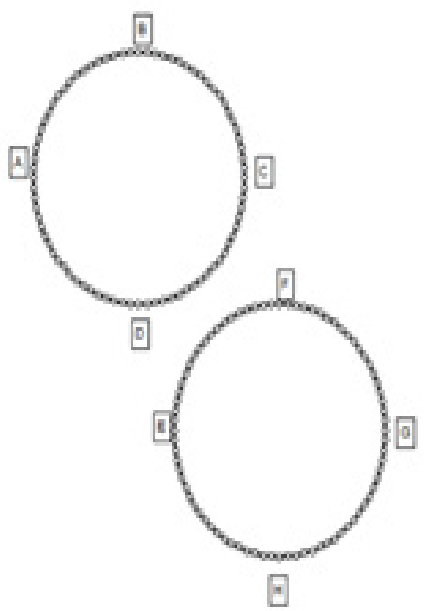

Figure 12: The location of deformation point review at schist.

Table 6: Value of total displacement and total normal stress tunnel at schist

\begin{tabular}{|c|c|c|c|c|c|c|c|c|}
\hline \multirow{2}{*}{ Modeling } & \multicolumn{7}{|c|}{ Total Displacement $(\mathrm{mm})$} \\
\cline { 2 - 10 } & Point A & Point B & Point C & Point D & Point E & Point F & Point G & Point H \\
\hline Condition of static loading & 0.18 & 0.3 & 0.35 & 0.23 & 0.25 & 0.38 & 0.23 & 0.23 \\
\hline $\begin{array}{c}\text { Condition of static loading with } \\
\text { joint effect }\end{array}$ & 0.21 & 0.36 & 0.45 & 0.24 & 0.27 & 0.51 & 0.33 & 0.24 \\
\hline Condition of dynamic loading & 0.07 & 0.46 & 0.56 & 0.11 & 0.11 & 0.56 & 0.49 & 0.25 \\
\hline $\begin{array}{c}\text { Condition of dynamic loading } \\
\text { with joint effect }\end{array}$ & 0.11 & 0.61 & 0.77 & 0.11 & 0.11 & 0.83 & 0.66 & 0.28 \\
\hline
\end{tabular}




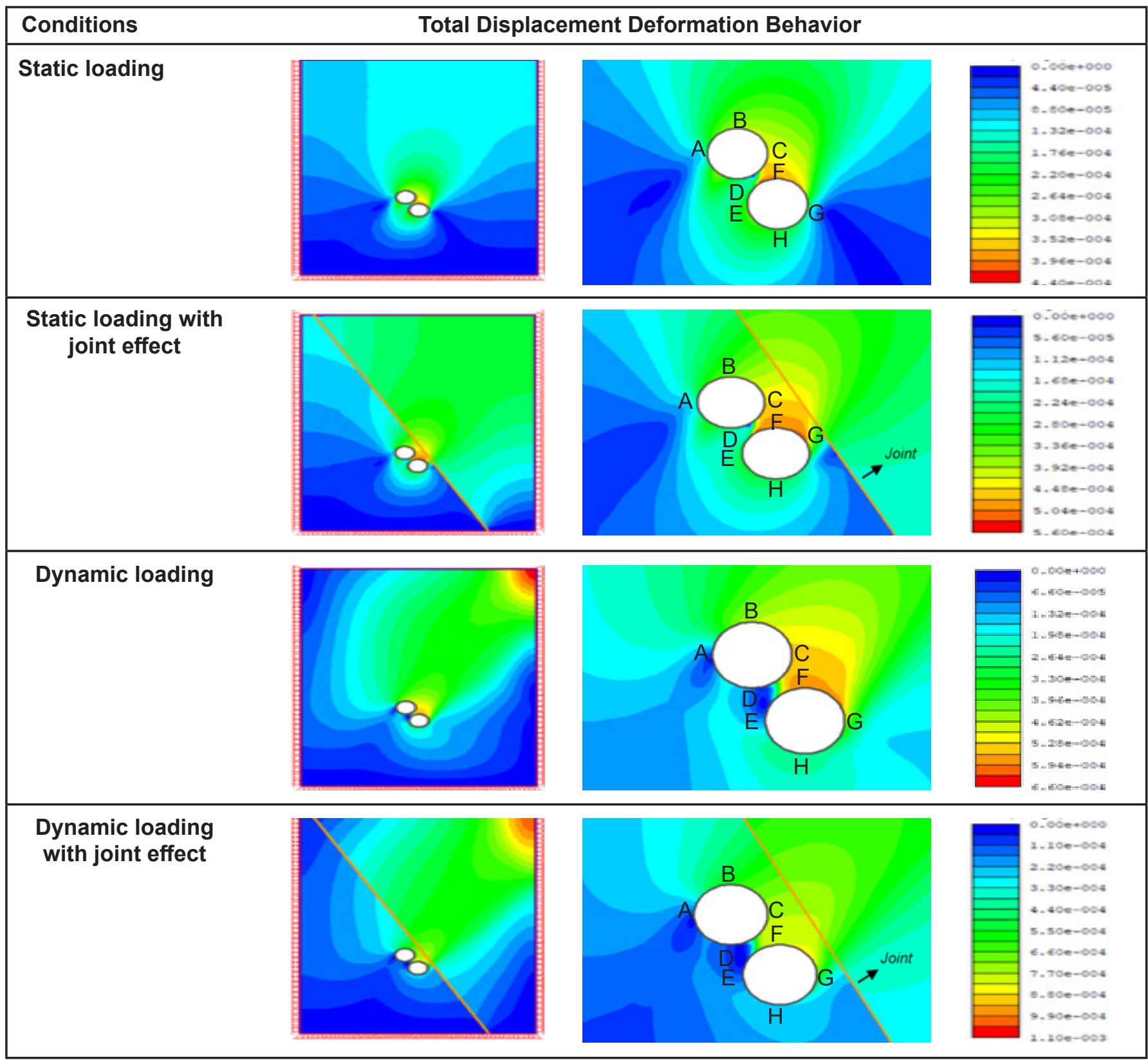

Figure 13: Tunnel deformation behavior at schist due to total displacement.

The analysis results of the existing slope modeling which represented by joint gave big impartial decrease of safety factor at gneiss by $0.43 \%$ and at schist by $25 \%$, this explains that the decline that occurs in the existing slope at gneiss and schist locations due to the geological structure effect does not have a significant impact.

The analysis results of the existing slope modeling under dynamic loading with geological structure (joint) effect explain that the decline that occurs at the gneiss location is $80 \%$ and $76 \%$ at schist location. This shows that the dynamic loading with the influence of joints greatly affect the safety factor significantly.

The above results illustrate that the effect of geological structures with dynamic loading greatly affects the slope stability of Poboya gold mine.
Therefore, it is necessary to take steps in order to prevent insecurity for the miners as well as the surrounding environment considering that Palu city area located in an earthquake prone zone. The steps that should be taken into consideration to avoid instability slope are:

1. Make the slope not too steep, because the steeper the slope the more susceptible it is to ground motion.

2. Install a ground motion monitoring device such as an extensometer or an early warning system that used as an early warning tool wenever there is an earthquake or ground motion.

3. Provide supporting technology on slopes as given by [23] which can be seen in Figure 14. 


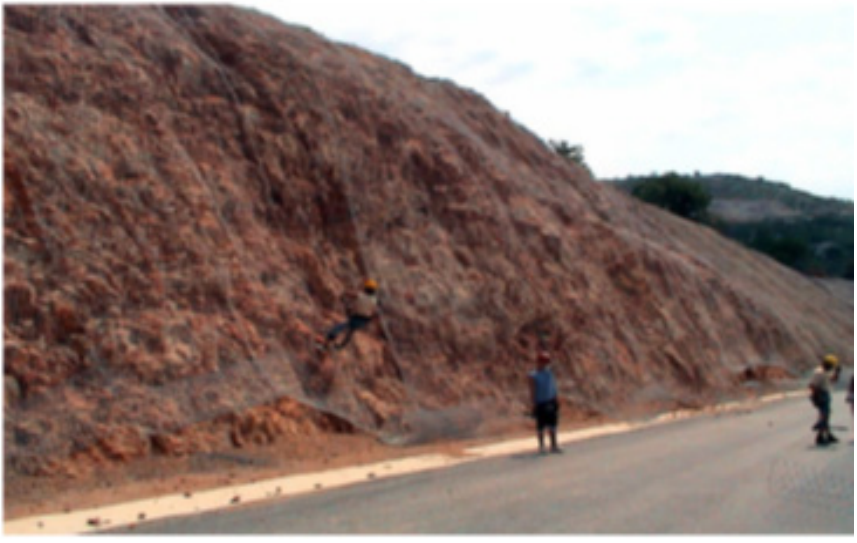

a)

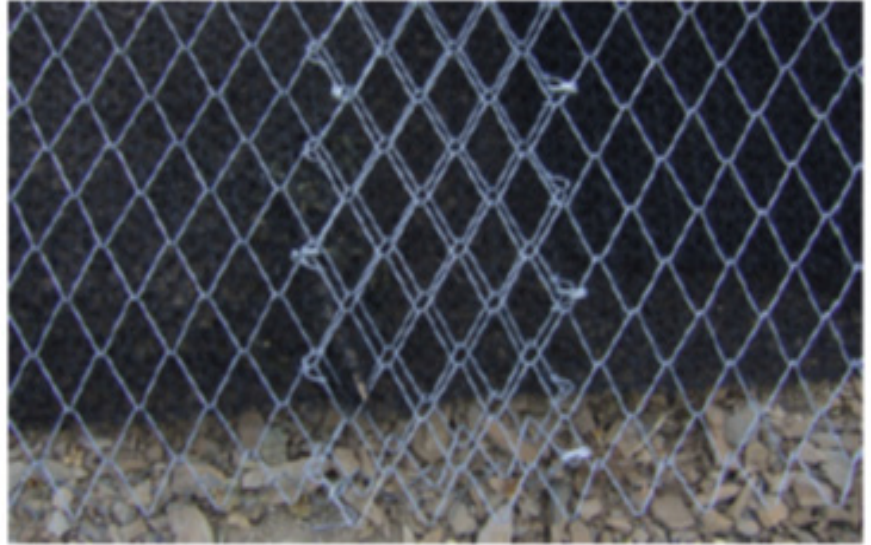

b)

Figure 14: Slope protection mechanism a) Slope protection with two galvanized wire bent knots and b) High bearing load knots [23]

\section{CONCLUSION}

The results of slope stability analysis using 2D Finite element method with the help of RS2 concluding that the effect of geological structure which represent by joint gave big impartial decrease of safety factor at gneiss location about $0.43 \%$ under condition of static loading and $80 \%$ of dynamic loading, while at schist location, the safety factor value decreased about $25 \%$ under condition of static loading and $76 \%$ of dynamic loading. Moreover, for tunnel stability, the existence of joint will increase the displacment for gneiss about $65 \%$ under condition of static loading and $84 \%$ of dynamic loading, while for schist has increased about $25 \%$ under condition of static loading and $54 \%$ of dynamic loading. This illustrates that the geological structures effect will reduce the safety factor value on the existing slope and increase the displacement value in the tunnel, hence it will affect the slope stability.

\section{REFERENCES}

1. Persada, Y. D., Ilham., Amaninida, H. D., Ariyanto, P. \& Gustono, S. T., (2021). First Conjecture of Gold Deposit Poboya, Palu Area Using HVSR Inversion Method. Jurnal Geofisika Eksplorasi, Vol. 07 (No. 01): 30-40.https://doi.org/10.23960/jge.V7/1.122

2. Junaedy, M., Efendi, R. and Sandra, S., Studi Zona Mineralisasi Emas Menggunakan Metode Magnetik Di Lokasi Tambang Emas Poboya. Online journal of Natural Science, Vol. 5 (No. 2): 209-222, August 2016.http://dx.doi.org/10.22487/25411969.2016. v5.i2.6708

3. Wawo, R.H.A., Sri, W., Nurliah, J. \& Firman, N. Y. (2017). Analisis Pengaruh Penambangan Emas Terhadap Kondisi Tanah pada Pertambangan Rakyat Poboya Palu, Provinsi Sulawesi Tengah. Jurnal Geomine, 5 (3): 116-119. https://jurnal.teknologiindustriumi.ac.id/index.php/JG/article/view/141
4. Liu, H., Yang, T., \& Qin, Y. (2011). Analysis of Excavating High Slope by Means of Finite Element Method. ICTE, pp 1660-1665.

5. Muller, J. (1979). Contributions to Engineering Geology and Slope Movement Investigations. In B. Voight (Ed.), Rockslides and Avalanches (Vol. Part 2, pp. 95-109). New York: Elsevier

6. Wyllie, D., \& Mah, C. (2004). Rock Slope Engineering (4th ed ed.). New York: Spon Press

7. Meng, J., Cao, P., \& Zhang, K. (2013). Jointed Rock Slopes Stability Analysis Using PFC2D. Geo-Congress, 385-394.

8. Sustriani, Y, (2012). Pengaruh Struktur Kekar Terhadap Kestabilan Lereng Dinding Bagian Barat Daya Dan Timur Laut Pada Desain Fase 6 Tambang Terbuka Batu Hijau PT. Newmont Nusa Tenggara. Tugas Akhir Program Studi Teknik Geologi, Semarang..

9. Saptono, S., Kramadibrata, S., Sulistianto, B., \& Irsyam, M. (2012) Studi Jarak Kekar Berdasarkan Pengukuran Singkapan Massa BatuanSedimen di Lokasi Tambang Batubara, Prosiding Simposium dan Seminar Geomekanika. Hal 1-88

10. Ramadhani, S., Rifa'l, A., Suryolelono, K. B., \& Wilopo, W. (2018). Slope Stability of Metamorphic Rocks Based on Rock Mass Classification at Poboya Gold Mine, Central of Sulawesi Province. International Review of Civil Engineering, Vol. 9 (No. 3): 91-97. https://doi.org/10.15866/irece.v9i3.13889

11. Azizi, F., 2000. Applied Analyses. London: E \& FN Spon

12. Griffiths, D.V., Lane, P.A.,(1999) Slope stability analysis by finite elements, Geotechnique, vol. 49 , no. 3 , pp. 387-403

13. Rocscience. (2011). Phase2, 2D Elasto Plastic Finite Element Program for Slope and Excavation Stability Analysis, Slope Stability Verification Manual. Toroto: Rocscience Inc 
14. Carlite, J. C. (1983). Geology, Exploration Geochemistry and Mineralization of the Tombolilato District,. Sulawesi, Indonesia.

15. Kavalieris, I., Van, L. T.M., and Wilson, M. 1992. Geological setting and styles of mineralization, North arm of Sulawesi Indonesia. Journal of Southeast Asian Earth Science, Vol. 7, (No.2-3): 113-129, February 1992. https://doi.org/10.1016/0743-9547 (92)90046-E

16. Wajdi, M.F., Santoso, S.B., Kusumanto, D. and Digdowirogo, S. Metamorphic Hosted Low Sulphidation Epithermal Gold System at Poboya, Central Sulawesi: A General Descriptive Review Sistem Emas Epitermal Sulfidasi Rendah dalam Batuan Metamorf di Poboya, Sulawesi Tengah: Tinjauan Deskriptif Umum, (2011).

17. Sukamto, Sumadirdja, H., Suptandar, T., ardjoprawiro, S., \& Sudana, D. Peta Geologi Tinjau Lembar Palu, Sulawesi. (Bandung: Pusat Penelitian dan Pengembangan Geologi, 1973).

18. Suhendro, B. (2000). Metode Elemen Hingga dan Aplikasinya (1st ed.). Yogyakarta, Indonesia: Jurusan Teknik Sipil, Fakultas Teknik Universitas Gadjah Mada.

19. Hammah, R., Yacoub, T., Corkum, B., \& Curran, J. (2005). The Shear Strength Reduction Method For the Generalized Hoek Brown Criterion. Alaska: Proceedings of the 40th U.S. Symposium on Rock Mechanics (USRMS): Rock Mechanics for Energy, Mineral and Infrastrukture Development in The Northern Regions.
20. Dawson, E., You, K., \& Park, Y. (2000). Strength-Reduction Stability Analysis of Rock Slopes Using the Hoek-Brown Failure Criterion. Trends in Rock Mechanics, 65-77

21. Pusgen. (2017). Peta Sumber dan Bahaya Gempa Indonesia 2017. Jakarta: Pusat Studi Gempa Nasional.

22. Golar, Muhammad, B., Muhammad, R., Rahmat, B., Bohari, Muhammad, F. P., Muhammad A. \& Laihi, A. (2019). Gold Mining and its Impact on Agricultural Land, Public Health, Violation of the Law: A Study on Poboya Traditional Mining, Palu, Indonesia. Indian Journal of Public Health Research and Development, 10 (10):924. https://www.researchgate.net/ publication/338137138_Gold_Mining_and_its_Impact_on_Agricultural_Land_Public_Health_Violation_of_the_Law_A_Study_on_Poboya_Träditional_Mining_Palu_Indonesia.

23. Grosic, M., Dugonjic, S., \& Udovic, D. (2008). Designing, Constructing and Monitoring of Slopes in Rock Mass in Croatia. Proceedings of the International Young Scholars' Symposium on Rock Mechanics, 463-469. 